\title{
Entre-culturas: vivendo entre Brasil e Israel
}

\author{
Raquel Teles Yehezkel* \\ Centro Cultural Brasileiro em Tel Aviv| Tel Aviv, Israel \\ raquel.yehezkel@gmail.com
}

Conheci Nissim no meu aniversário de 22 anos. Ele também tinha 22. Estávamos na Bolívia, no caminho de Machu Pichu, em janeiro de 1983 - eu indo, ele voltando. Posso dizer que ao encontrá-lo, encontrei também minha outra casa, outra parte da minha vida. Desde então, caminhamos juntos, buscando construir pontes entre nossas culturas.

Ele é de Israel, eu, de Dores do Indaiá, no interior de Minas, Brasil. Ao longo do caminho, muitas vezes, as diferenças culturais foram barreiras, outras, pontes. Tínhamos o background comum da geração nascida nos anos 60, recém-globalizada pela música, pela literatura e o cinema. A geração do rock pop e progressivo, do cinema experimento, da liberação sexual, da rebeldia dos filhos da classe média. Eu vinha de Beagá do Cine Pathé e da Sala Humberto Mauro, dos shows no Palácio das Artes, no Francisco Nunes e no DCE, da Fafich da UFMG, das turmas de rua e de colégios, dos grupos de músicos-amigos, da Alquimia e comidas naturais, de famílias do interior de Minas - há gerações conectadas à terra, às águas e ao firmamento, e irmãos proprietários de livrarias. Ele, recém-saído da Tzahal (Forças de Defesa de Israel), quatro anos no Modiyn (Serviço de Inteligência), serviu no Sinai e em Ramat Hasharon, de familias de imigrantes saídas sem nada do Iraque ao final da II Guerra, da primeira geração nascida na nova Terra de Israel, estudou no Netsah LeBanim (sim, chavash kipá / usava solidéu até os 14 anos), na prestigiosa High School Aamal de Petach Tikva e no Joseph College da Universidade de Tel Aviv, frequentou o Cine Paris e a hof (praia) Hatzuk de Tel Aviv, foi corredor de maratona, atravessava correndo os pardesim (pomares) de laranja, que ligavam Petah Tikva até o mar. Entendia - e entende ainda - tudo de música, de cinema, de literatura e de esportes. Leu de Tolstoi e Bashevis Singer a Jorge Amado e Eli Amir. Me aplicou em Arik Einstein e na música israelense de todos os tempos e eu o apliquei no melhor da música popular brasileira.

Nessa travessia, nos construímos entre amor, rachaduras e frestas - por intermédio de Arik Einstein, Shmulik Kraus, Shalom Hanoch, Shlomo Artzi, Poliker, Zohar, Ishay Levi, Bery Saharov, Amir Levi, Ehud e Meir Bannay, Caetano, Cazuza, Raul, Almodovar. Entre corridas e caminhadas, sempre lendo antes de dormir,

\footnotetext{
* Graduada em Letras pela Universidade Federal de Minas Gerais e Diretora do Centro Cultural Brasileiro em Tel Aviv.
} 


\section{Arquivo Maaravi}

acompanhando seriados e cinema, ouvimos juntos tudo de Dire Straits, Eric Clapton, Neil Young, Peter Green, Leonardo Cohen, Joe Coker, Tom Waits, Rob Robertson, The Band, Bob Dylan. Fundamos juntos a Editora Leitura de Belo Horizonte.

Eu tinha uma atração e uma simpatia pela história e pela cultura do país dele, ele, pelo meu. De tudo, talvez o que mais nos tenha conectado desde e sempre tenha sido a forma de viver de nossas famílias. Ambos viemos de casas muito calorosas, com irmãos unidos que se importam muito uns com os outros e pais dedicados à família, tios, primos e sobrinhos muito próximos. Fui abraçada pela família dele e ele se adaptou à minha com facilidade - apesar de manter sempre a reserva intrínseca à sua personalidade. Aos poucos, ele se tornou um israelense meio brasileiro, e eu, uma brasileira bem israelense.

Cheguei a Israel ao completar 23 anos, em Pessach (Páscoa judaica), em abril de 1984, no $36^{*}$ aniversário desse país. Dos costumes religiosos não entendia nada, mas logo me adaptei. Já vinha ligada ao país pela literatura e o cinema, e também pela história que nos unia desde a Inquisição e a formação do Brasil, carregando os sobrenomes Cardoso, Oliveira, Pinto, Campos e Carvalho dos meus avós, cristãos-novos no interior do Brasil. Na terra da minha mãe, em Bom Despacho, diziam que os Cardoso casavam entre si, não se misturavam, casando ela mesma dessa forma, com meu pai, Teles Carvalho, parentes com ancestrais comuns em Luz.

E nessa longa cadeia, nas voltas que a vida dá, abracei o judaísmo e dediquei boa parte da minha vida ao aprendizado e à aproximação dessas duas culturas, que, apesar de tão diferentes, são ricas, informais, criativas, calorosas e múltiplas. No Brasil, tinha que explicar Israel; em Israel, explicar o Brasil. Estudei Letras, História, participei do Núcleo de Estudos Judaicos da UFMG, fui editora, escrevi e adaptei livros por 15 anos e, depois, diretora do Centro Cultural Brasileiro em Tel Aviv por mais uns tantos. Entre um lugar e o outro, criamos três filhos que se amam, sendo bem diferentes entre si: um rabino, um empresário e um artista.

Entre descidas e subidas, reconheço que absorver amplamente língua e cultura implica transformação e dor, pois nunca mais nos encontramos totalmente nem em uma, nem em outra. Entre-culturas.

Recebido em: 13/09/2019.

Aprovado em: 23/09/2019. 